\section{As oficinas e o} trabalho penal dos condenados da Casa de Correção de Porto Alegre (1895-1930)

\section{Tiago da Silva Cesar [*]}

[*] Professor do Curso de História e do Programa de Pós-graduação em História/Universidade Católica de Pernambuco (Unicap). Recife (PE), Brasil. tiago.cesar@unicap.br

ORCID: https://orcid.org/0000-0003-1044-9314
Resumo: $\mathrm{O}$ artigo analisa a implementação do sistema penitenciário na Casa de Correção de Porto Alegre, promovido pelos mandatários gaúchos reunidos em torno do Partido Republicano Rio-grandense (PRR), a partir do início do governo de Júlio de Castilhos, até o fim da República Velha, com a ascensão de Vargas (1895-1930). Com base em farta documentação (mensagens, relatórios, regulamentos, jornais, fotografias etc.), e com o apoio da historiografia especializada, tentou-se reconstruir em parte os esforços empreendidos pelos referidos governantes para transformar o maior depósito de indesejáveis do Estado num modelo de eficácia penal-carcerária, especialmente através de uma política de fomento à geração de lucro por meio do emprego da mão de obra encarcerada em oficinas dispostas no re cinto prisional. Os presupostos teóricos questionam a equiparação do êxito econômico a um possível sucesso do regime correcional.

Palavras-chave: Casa de Correção de Porto Alegre; Trabalho penal; Partido Republicano Rio-grandense (PRR).

\section{The workshops and the penal work of the convicts of the Casa de Correção de Porto Alegre (1895-1930)}

\begin{abstract}
The article analyzes the implementation of the penitentiary system at the Casa de Correção de Porto Alegre, promoted by Rio Grande do Sul government representatives gathered around the Rio Grande Republican Party (PRR), from the beginning of the government of Júlio de Castilhos, until the end of the Old Republic, with the rise of Vargas (1895-1930). Based on abundant documentation (messages, reports, regulations, newspapers, photographs, etc.), together with the support of specialized historiography, attempts were made to partially reconstruct the efforts undertaken by the aforementioned governments to transform the largest deposit of undesirables in the State in a model of penal-prison efficacy, especially through a policy of promoting profit generation through the use of incarcerated labor in workshops located in the prison. The theoret ical assumptions question the equation of economic success with a possible success of the correctional regime.
\end{abstract}

Keywords: Casa de Correção de Porto Alegre; Penal work; Partido Republicano Rio-grandense (PRR). 
$\mathrm{F}$ iliamo-nos à historiografia sobre a história social das instituições punitivas que analisa criticamente a ideia de passividade disciplinar no que diz respeito à transformação de encarcerados em trabalhadores dóceis e morigerados. Mas, por outro lado, há de se concordar que passagens por instituições de privação de liberdade como a Casa de Correção de Porto Alegre, durante a República Velha, resultavam numa experiência marcante na vida de qualquer indivíduo. Marcante, poder-se-ia dizer, em vários sentidos, mas, principalmente, por permitir uma experiência/aprendizagem cívica, traduzida numa "verdadeira lição sobre o que significava ser pobre e brasileiro" (Chazkel, 2009, p. 8-9).

Somente essa aprendizagem cívica em negativo já mereceria uma justificada atenção. Mas, se a isso acrescentamos que foi precisamente sob o novo regime republicano que o referido estabelecimento alcançou as maiores cifras de presidiários, desde a abertura em 1855, não cabe dúvidas de que sua importância como maior depósito de indesejáveis da antiga província de São Pedro o converte numa oportunidade ímpar de estudo acerca do modelo correcional implementado pelo Partido Republicano Rio-grandense (PRR).

Não custa lembrar que, durante o Segundo Reinado (1840-1889), os elementos do coquetel disciplinar idealizado para as principais prisões brasileiras seguiam as mesmas recomendações apresentadas, primeiramente, por reformadores e, posteriormente, discutidas nos principais congressos penitenciários contemporâneos (Albuquerque Neto, 2017, p. 4650). Exceptuando as cansativas discussões sobre o sistema alburniano ou pensilvânico, ${ }^{1} \mathrm{em}$ geral, apresentavam-se e apoiavam-se propostas de estabelecimentos que albergassem oficinas onde os condenados à prisão com trabalho pudessem não somente cumprir suas penas, conforme a prescrição da lei, mas também se regenerarem moral-condutualmente, ${ }^{2}$ além de com seu lucro poder sufragar ao menos parte dos gastos carcerários. Sublinhe-se que, nesse almejado proceso de emenda, tanto a escolarização, como a atenção religiosa não deixariam de ter um papel importante.

\footnotetext{
${ }^{1}$ O sistema penitenciário implantado nas cadeias de Filadélfia, daí o nome de filadélfico ou pensilvânico, por sua origem, que ocorreu por volta de 1792 e é atribuída à influência quaker. Primeiramente se caracterizou pelo solitary confinement, que era aplicado, segundo Duprat (1980, p. 91 e 114), somente a uma pequena minoria de "grandes criminosos" e de maneira temporária, determinada pelos juízes. Ainda conforme essa autora, o sistema celular de reclusão ininterrupta (dia e noite), com ou sem trabalho, só se generalizaria em 1829, na prisão de Cherry Hill (Filadélfia). Já Tocqueville e Beaumont datam de 1786 o "nascimento do sistema penitenciário" nos Estados Unidos, como conseqüência dos esforços dos quakers com respeito à abolição da pena de morte, mutilação e chicote da legislação da Pensilvânia, implantando em seu lugar o encarceramento solitário sem trabalho para os réus de crimes capitais. Esse sistema surge na prisão de Walnut Street, enquanto a trajetória da de Auburn só começará muito mais tarde, em 1816 (Tocqueville; Beaumont, 2005, p. 106-107 e 110). O sistema auburniano ou silence system consistia em trabalho diurno coletivo, em silêncio, e encarceramento solitário pela noite.

${ }^{2} \mathrm{O}$ inglês John Howard já havia considerado o trabalho obrigatório como um dos elementos-chave para a reforma dos estabelecimentos de reclusão em sua obra The state of the prisons in England and Wales, with preliminary observations, and an account of some foreign prisons (1777). Para este trabalho utilizou-se a seguinte versão: Howard (2003).
} 
Não obstante, e salvo escassas excessões, incluída a própria Casa de Correção de Porto Alegre, o referido sistema não vingou como se esperava sob o regime monárquico. No estabelecimento gaúcho, por exemplo, a única e efêmera experiência com oficinas ocorreu poucos meses após a sua inauguração (1855). Com o cessar delas, naquele ano, o assunto apenas voltaria à baila nos relatórios dos presidentes da província, mas nunca com encaminhamentos práticos (Cesar, 2015, p. 130-131). A missão caberia, de fato, aos novos mandatários republicanos.

Com efeito, o golpe de 15 de novembro de 1889 instaurou a República no Brasil, e como tantos outros temas e assuntos em que o novo regime desejava imprimir um selo próprio, também a questão penitenciária passou a ser encarada como algo a ser reformulado e ordenado. O presidente Prudente José de Morais Barros, em mensagem ao Congresso Nacional, de 3 de maio de 1895, radiografava o problema com as seguintes palavras:

Por igual, precisa ser organisado o systema penitenciario da Republica, afim de que se possa dar o devido cumprimento as prescripções do codigo penal.

Não existe ainda edificio cellular especial, nem foi tam pouco installado uma penitenciaria agrícola para effectividade das penas comminadas n'aquelle codigo. E esta providencia é tanto mais necessaria quanto é certo não haver actualmente uma unica colonia penal, visto que cessou por força do decreto legislativo n. 226 de dezembro próximo findo a existencia do presidio de Fernando de Noronha.

A propia colonia correccional de Dois Rios, fundada pelo governo transacto, nos termos do decreto $n .1794$ de 11 de setembro de 1894 e em observancia do decreto legislativo n. 145 de 11 de julho de 1893, não foi convenientemente installada, attenta não só a impropriedade do local, em razão da difficuldade das communicações, como tambem os grandes onus que d'esse facto resultam para os cofres publicos, tornando elevadissimo o respectivo custeio (A Federação, 16 maio 1895, p. 1).

Sem contar com um organizado sistema penitenciário e edificações para o cumprimento do regime de isolamento celular, nem mesmo com uma penitenciária agrícola ou colônia penal que substituisse o desativado Presídio de Fernando de Noronha, somado ao insucesso da Colônia Correcional de Dois Rios, não restava, de fato, outra coisa a fazer que promover o "systema penitenciario da Republica".

Tudo indica que os republicanos sul-rio-grandenses, chefiados por Júlio Prates de Castilhos, levaram a sério o desafio, pois nem bem silenciadas as trincheiras da Revolução Fe- 
deralista, ${ }^{3}$ em agosto de 1895, medidas passaram a ser tomadas no sentido de atender ao estipulado pelo Código Penal de 1890. O próprio Castilhos, que há uma década visitara a então Cadeia Civil de Porto Alegre, compondo uma comissão de notáveis que a caracterizou como uma "inquisitorial prisão" (Pesavento, 2009, p. 37), informou em mensagem de 14 de outubro de 1895, na ocasião da submissão a exame do projeto de orçamento da receita e despeza do Estado para 1896, que

vae ser organisado o serviço interno d'aquelle estabelecimento [Cadeia Civil de Porto Alegre], onde começarão em breve a funccionar algumas officinas provisorias, cujo trabalho será devidamente regularisado, até que se torne possivel a instituição normal do moderno sistema penitenciario (A Federação, 16 out. 1895, p. 2).

Pouco depois, enfatizou, pelo mesmo órgão, que nada escapava à "illustrada attenção os prejuizos e males, moraes e materiaes, que decorrem da absoluta falta de um serviço penitenciario entre nós" (A Federação, 5 nov. 1895, p. 1).

Figura de vulto do PRR, a prestação de contas e a mensagem de Julio de Castilhos à Assembleia Legislativa, acerca da organização penitenciária do Estado, não foi meramente protocolar. Tanto é assim que, poucos meses depois, Borges de Medeiros, então chefe de Polícia, propôs uma reforma nos regulamentos da Cadeia Civil de Porto Alegre, concretizada pelo ato $\mathrm{n}^{\underline{0}} 24$, de 29 de fevereiro de 1896 . O referido dispositivo estipulava um regulamento provisório com o objetivo de discriminar "os serviços e deveres dos empregados da Casa de Correção", baseado num projeto elaborado pelo advogado Germano Hasslocher, enquanto não se construísse "um estabelecimento penitenciário especial" (Cesar, Szczepaniak, 2019, p. 293).

Diante de uma população carcerária que superava as cinco centenas de reclusos (veja-se o Gráfico 1) e que acarretava, já na passagem do século XIX para o XX, gastos consideráveis ao Estado, não é de estranhar que as oficinas e o trabalho penal dos condenados tenham ressurgido e sido apresentados à sociedade como a panaceia para combater velhos e variados males.

Numa extensa matéria de capa, intitulada "Notas econômicas", copiada do jornal carioca Correio da Manhã, de 7 de janeiro de 1920, e publicada no número da A Federação: Orgam do Partido Republicano, de 28 de janeiro de 1920, o articulista Mario Guedes arrancou suas con-

3 “Guerra civil entre federalistas partidários de Gaspar Silveira Martins, os chamados 'maragatos', e republicanos partidários de Júlio de Castilhos, os 'pica-paus', que conflagrou o Rio Grande do Sul, Santa Catarina e Paraná entre fevereiro de 1893 e agosto de 1895. O conflito envolveu amplas forças militares locais e ainda remanescentes da Revolta da Armada, aliados dos federalistas, e se encerrou com a vitória dos republicanos". Abreu, Alzira Alves de. Verbete "Revolução Federalista". Disponível em: <https://cpdoc.fgv.br/sites/default/files/verbetes/primeira-republica/REVOLU\%C3\%87\%C3\%830\%20 FEDERALISTA.pdf>. Acesso em: 2 mar. 2020. 
siderações sobre o "pequeno exército" de presidiários que, segundo seus cálculos, rondava então os seis mil em todo o Brasil, afirmando categoricamente que "faz-se preciso dar um fim economico a toda essa população de sentenciados". Um fim econômico, conforme sua explicação, que não consistisse "somente no exercício de certos officios communs a certas penitenciarias", mas num "ensino profissional adaptado às condições locaes, ou da região. Ou por outra: na adopção de determinados officios indicados pelo 'meio"', que atendessem os "resultados commerciaes, ou industriaes, de taes officios", tal como se dava, exemplificava, na Casa de Correção de Porto Alegre (A Federação, 28 jan. 1920, p. 1; Correio da Manhã, 7 jan. 1920, p. 2).

Para Guedes, no estabelecimento sulino se fazia realidade o que para ele devia ser reproduzido nacionalmente, a saber: concentrar numa penitenciária todos os presos do Estado para proporcionar-lhes um ofício, a fim de que à sua soltura, retornassem cada qual às suas localidades de origem, e lá servissem como mão de obra especializada. Somente assim, acreditava, a penitenciária "exercerá um alto papel de educação" e "será escola profissional para adultos", e os presos, deixando de ser um "elemento de desordem", passarão a ser instrumentos de "disseminação de instrucção profissional por todo o Estado" (A Federação, 28 jan. 1920, p. 1; Correio da Manhã, 7 jan. 1920, p. 2).

A essa altura, fazia pelo menos vinte anos que a Correção vinha demonstrando alcançar "resultados effectivos", fruto do trabalho presidiário realizado desde as pioneiras oficinas de marcenaria, chapelaria, sapataria, alfaiataria, ferraria e fotográfica (Medeiros, 1900, p. 16-17). Já no início do século XX, o estabelecimento porto-alegrense havia-se constituído como um símbolo da modernidade penal-carcerária promovida pelo PRR, o que não deixava de ser, também, uma importante propaganda à regeneração propalada pelo novo regime.

De fato, na introdução à mensagem presidencial de Julio de Castilhos, publicada em novembro de 1900, chegou-se a dizer que a Casa de Correção "talvez [fosse] na Republica o primeiro estabelecimento no seu genero", que graças à "perfeição dos methodos e sistemas ahi ensaiados e praticados tornam-n'o apto a desafiar o cotejo com quaesquer outros estabelecimentos que se destinem aos mesmos fins" (A Federação, 27 nov. 1900, p. 1).

Como colocamos de manifesto, os gestores republicanos gaúchos, de olho no que se passava em outras paragens brasileiras, não se encabulavam em afirmar, diante de relatórios que demonstravam ineficiência quanto às disposições corretivas promovidas inclusive pela congênere do Rio de Janeiro, ${ }^{5}$ que o "estabelecimento penitenciario do Rio Grande do Sul

\footnotetext{
${ }^{4}$ Todos os relatórios de presidentes do Estado do Rio Grande do Sul consultados estão disponíveis em: < http://ddsnext. crl.edu/titles/182?c=4\&m=0\&s=0\&cv=0\&r=O\&xywh=-230\%2C-96\%2C2698\%2C1903>. Acesso em: fev. 2020.

${ }^{5}$ Em fevereiro de 1905 se publicou uma extensa matéria sobre a Casa de Correção do Rio de Janeiro em duas partes no Jornal do Commercio. Nela se fez alusão ao relatório produzido pela comissão nomeada pelo ministro e secretário de Estado da Justiça e Negócios Interiores para inspecionar o referido estabelecimento, composto pelos senhores Sá Vianna,
} 
póde, sob todos respeitos, servir de modelo aos estabelecimentos [...] dos demais pontos da Republica" (A Federação, 1 mar. 1905, p. 1).

E não era para menos, quando o próprio presidente da República, Francisco de Paula Rodrigues Alves, em mensagem ao Congresso Nacional, de 3 de maio desse mesmo ano, afirmava que "é de grande necessidade dotar-se esta capital com um estabelecimento penitenciario que satisfaça as exigencias do codigo penal e assegure aos condemnados meios efficazes de regeneração" (A Federação, 8 maio 1905, p. 1). Vale lembrar que a Colônia Correcional de Dois Rios, havia recebido há apenas dois anos, a primeira leva de presos, sendo, à época, pelo atraso e gastos realizados, motivo de críticas e charges satíricas (Santos, 2009, p. 134-136).

Destarte, não é preciso se deter muito nos valores da Tabela l para constatar quão lucrativas as oficinas da Casa de Correção sulina vieram a ser ao longo do tempo, e, consequentemente, porque se redobrou a importância disciplinar do trabalho no recinto penal. Os lucros e a possibilidade de aliviar os cofres públicos geraram, como era de se esperar, uma forte pressão sobre os encarcerados, principalmente por parte da administração judiciária e carcerária do Estado, embora a imprensa oficial sempre se empenhasse em apresentar o êxito econômico como se fosse a maior prova do êxito do sistema correcional implementado, ou, simplesmente, como se da mesma coisa se tratasse.

\section{O selo normativo-correcional}

Em contestação dada ao colaborador da seção Dia a dia, da Folha Nova, que, pelo visto, havia criticado, em fevereiro de 1895, o regime da Cadeia Civil de Porto Alegre, dando certamente a entender ser de responsabilidade do atual governo corrigi-lo, dispararam os agentes do PRR, através de seu orgão oficial, "que o governo do Estado já de ha muito cogita em melhorar e reformar o sistema penitenciario que veiu encontrar estabelecido", fazendo constar, ainda, que a

completa organisação dos serviços públicos ocupa a attenção do dr. presidente do Estado, que já teria feito importantes reformas administrativas e encaminhado outros melhoramentos, si todo o seu tempo, toda a sua attenção não fossem desviados para as medidas de segurança e de ordem que, com primazia incontestavel, são solicitadas

Moraes Sarmento, e Bartolomeu Portella (Jornal do Commercio, 16 fev. 1905, p. 1; 17 fev. 1905, p. 2). Segundo Sant’Anna, já na última década do século XIX, eram muito raras as notícias periodísticas encomiásticas acerca das instituições prisionais da Capital Federal, e mais escassas ainda parecem ter ficado, conforme avançou-se sobre o XX, quando, ao contrário, choveram denúncias de todo tipo nos jornais cariocas (Sant’Anna, 2010, p. 136-148). 
a todo o momento contra as constantes e execrandas correrias dos criminosos perturbadores da paz do Rio Grande do Sul (A Federação, 8 fev. 1895, p. 2).

Tudo indica que a crítica feita, assim como a resposta recebida, teve como pano de fundo a todavia inacabada Revolução Federalista. Mas a cutucada talvez tenha feito os castilhistas se mexerem, pois, como já vimos, em fevereiro de 1896, seria chancelado o primeiro regulamento do período republicano para o principal estabelecimento prisional do Estado do Rio Grande do Sul. A pressa, é uma hipótese, pode ter sido a razão pela qual o referido instrumento fora promulgado em caráter provisório. Não obstante, o novo conjunto normativo, que contava com mais de 210 artigos, acabou regendo a maior prisão sulina durante mais de 17 longos anos.

O presente articulado constituía uma autêntica peça de ordenação carcerária, fruto do pensamento positivista comungado pelos mandatários republicanos gaúchos. Tanto que a sua substituição, em 1913, se deu antes pela necessidade de atualização do organograma da casa, a fim de acompanhar as demandas penitenciárias e administrativas, pressionadas pelo aumento do movimento carcerário, do que devido à obsolescência ideológica do modelo penitenciário vigente. A essência, portanto, seguia sendo a mesma, ainda mais quando o novo regulamento chancelava, novamente, a manutenção da Casa de Correção como lugar de execução da pena de prisão com trabalho, além do de prisão simples, enquanto inexistisse o pretendido "estabelecimento penitenciário especial" do estado do Rio Grande do Sul. ${ }^{6}$

A principal inovação trazida pelo dispositivo de 1896 foi, precisamente, a introdução e organização das oficinas, desaparecidas desde 1855 do recinto penal porto-alegrense, durante seu primeiro ano de funcionamento, apesar da sua importância para o cumprimento das penas de prisão com trabalho e enquanto elemento disciplinar/moralizador.?

Além da introdução do trabalho no recinto penal, base da ideologia correcionalista que perpassou o século XIX, outros hábitos e valores compuseram, conjuntamente, as técnicas e estratégias disciplinares voltadas à regeneração do preso. Embora saibamos, perfeitamente, que nunca se produziram encarcerados docilizados, não deixa de surpreender a atenção empenhada em querer transformar deliquentes - empedernidos ou não - em trabalhadores morigerados.

\footnotetext{
${ }^{6}$ Artigo 10 do Regulamento de 1913 (Seminário de Pesquisas do Arquivo Histórico do Rio Grande do Sul, 1., 2001. Porto Alegre. Anais... Porto Alegre: AHRS, 2001, s.p.). Os demais regulamentos mencionados no texto constam dessa edição dos Anais.

${ }^{7}$ Em 1855, portanto, no mesmo ano de sua inauguração, funcionaram as primeiras e únicas oficinas implementadas na Cadeia Civil de Porto Alegre, durante todo o período imperial. As mesmas se regiam por um documento específico, anterior inclusive ao primeiro regulamento daquele estabelecimento (27-02-1857), intitulado Regulamento provisorio para o deposito de objectos provinciaes, e regimen das officinas estabelecidas na cadêa civil d'esta capital (Bello, 1855, p. 1-6). Pelo presente instrumento se estipulava a abertura de nove oficinas: alfaiates, sapateiros, correeiros, carpinteiros, tamanqueiros, trançadores, tanoeiros, marceneiros e costureiras.
} 
Decerto, essa transformação não seria fruto de um processo que se daria da noite para o dia, mas sim através da imposição de um controle disciplinar sobre os mais diferentes aspectos da vida em reclusão. E como disciplina se aprende disciplinando-se, desde a entrada à saída do recinto penal, tudo se organizava em função de uma rotina meticulosamente controlada pelos ponteiros do relógio.

Se tempo é dinheiro, como diria o chavão, e será literalmente no caso do estabelecimento sul-rio-grandense, também significava aqui organização: nada podia escapar ao fracionamento do tempo pensado para cada passo dado com os trajes da Correção. Tanto que se tomava o primeiro dia de ingresso do condenado como uma iniciação, simbolicamente representada numa espécie de rebatizamento com a concessão de um número que, a partir de então, se utilizaria "como nome e pelo qual será conhecido" o detento. ${ }^{8}$

Vale acrescentar que, se a Casa de Correção não era uma instituição hermética ao exterior, ao menos o seu cotidiano deveria compreender e significar uma experiência totalizante, já que se exigia do detento uma autêntica imersão num processo de aprendizagem de aquisição de hábitos e valores caros aos homens bons daquela sociedade sul-rio-grandense e, por que não, brasileira. Desigual, hierarquizada e repressora, não estranha, portanto, que se tenha dado tanta importância à profissão e ao acúmulo de um pecúlio, mas também à honra e à família e, não menos, à obediência e respeito às autoridades tão destacadamente impressa nos regulamentos.

Uma das várias obrigações impostas aos condenados era saber, justamente, quanto custavam individualmente ao Estado, ${ }^{9}$ além de terem que suportar em silêncio, resignados e dispostos ao processo de regeneração. Trabalho, submissão ${ }^{10}$ e moralização, ${ }^{11}$ deveriam ser a simbiose do projeto correcional sulino.

Claro que para isso não só se lançava mão de guardas e empregados, mas também de outros castigos devidamente estipulados para dissuadir ou punir os mais renitentes. Os guardas, em concreto, eram os pés, braços e olhos do administrador, pois estavam incumbidos de velar pelo cumprimento de grande parte das determinações atribuídas aos presos, já fosse advertindo-os ou, em seu caso, comunicando diretamente suas faltas ao referido

\footnotetext{
${ }^{8} \S 10$ do artigo 43 do regulamento de 1896 (Seminário de pesquisas do AHRS, 2001, s.p.).

${ }^{9}$ Artigo 103 do regulamento de 1896.

10 O regulamento de 1913 está cheio de referências ao acatamento, submissão e respeito às autoridades. No artigo 40, por exemplo, exigia-se aos presos que atuassem com "correção e acatamento" quando penetrassem no recinto empregados de serviço, assim como "quando algum empregado da casa lhes falar, levantar-se-ão para ouvi-lo". Nas normativas de 1896, ao menos quatro artigos se referiam a penas ou castigos disciplinares a quem desobedecesse à hierarquia (artigos 164, 165, 167 e 169).

11 “En la primera mitad del siglo XIX, el término moralización es de un uso muy frecuente tanto en el discurso político como en el discurso culto. Concretamente designa una estrategia de sumisión de las clases trabajadoras y de las clases llamadas peligrosas a las nuevas normas de funcionamiento de la sociedad" (Donzelot, 1991, p. 37).
} 
superior. No regulamento de 1913, o primeiro dever do guarda consistia em "exercer a maior vigilância sobre os condenados, espreitando suas ações e movimentos, observando se eles cumprem com seus deveres [...]"..12 Através deles, o administrador se fazia onipresente.

Evidentemente que no dia a dia podiam e nasciam variados tipos de cumplicidades e inclusive certas familiaridades entre vigilantes e vigiados, mas o papel dos primeiros, mesmo que eventualmente fizessem concessões e vistas grossas, consistia em não deixar as coisas saírem de controle, o que por sua vez lhes garantia o emprego e evitava punições indesejadas. Isso constituía uma espécie de engrenagem que, mesmo desgastada, devia seguir girando no sentido horário do regime.

O administrador, sucessor do antigo carcereiro, teve com a abertura das oficinas o seu poder ainda mais fortalecido, a ponto de se poder dizer que suas funções incidiam sobre a vida e a morte dos sentenciados, já que praticamente tudo passava por ele: comida, ${ }^{13}$ vestes, comunicação presencial ou por cartas, ${ }^{14}$ trabalhos em serviços do estabelecimento, ${ }^{15}$ escolha do tipo de oficina e seu lugar nas mesmas, ${ }^{16}$ baixa e prestação de contas dos pecúlios dos falecidos e a respectiva comunicação às autoridades competentes, ${ }^{17}$ incluindo, notadamente, os castigos e recompensas que seriam dados conforme seu "juízo". ${ }^{18}$

Isso é apenas uma palhinha, havia muito mais, como por exemplo, registrar "reservadamente" em um livro "especial", "todas as observações sobre a conduta dos sentenciados, as suas tendências, os fatos em suma pelos que se possa formar seguro juízo sobre o seu caráter", com o objetivo de fornecer oportunamente às autoridades competentes, "as informações que tiver", especialmente quando reincidissem. ${ }^{19}$

Em um dos processos-crime analisados por Lisiane Cruz, em sua dissertação de mestrado sobre o julgamento de menores pela comarca de Santa Maria (1910-1927), além dos dados coletados pelo Gabinete de Identificação e Estatística do Estado do Rio Grande do Sul, anexou-se ao mesmo informações registradas na Casa de Correção de Porto Alegre, fornecidas àquela comarca pelo então administrador da Casa de Correção, Plauto de Azevedo. Segundo o zeloso funcionário:

\footnotetext{
${ }^{12}$ Artigo 24 do regulamento de 1913.

${ }^{13}$ Artigo 139 do regulamento de 1896.

${ }^{14}$ Artigo 184 do regulamento de 1896.

${ }^{15}$ Artigo 104 do regulamento de 1896.

${ }^{16}$ Artigo 14, § 70 do regulamento de 1896.

${ }^{17}$ Artigo 186 do regulamento de 1896.

${ }^{18}$ Artigo 162 do regulamento de 1896.

${ }^{19}$ Artigo 14, §14 do regulamento de 1896. Destaques do original.
} 
Ottilio [...] é vulgarmente conhecido por "Jacaré", e foi posto em liberdade, em 16 de setembro de 1920, por ter cumprido a pena de 2 annos de prisão, como vereis das inclusas annotações.

É de péssimos antecedentes, tanto na prisão como fóra da prisão. Foi praça do corpo de bombeiros nesta cidade.

João [...] é nome usado, falsamente.

Trata-se do contumaz gatuno EDMUNDO [...], como podereis ver das inclusas informações.

Tem elle uma mancha, de origem syphilitica, em um das faces.

Podereis obter sua photographia e mais signaes de identidade, do Gabinete de Identificação, pedindo ao Dr. Chefe de Policia.

Plauto d' Azevedo - Administrador ([Arquivo Histórico Municipal de Santa Maria] AHMSM. PROC292, 1923, f. 85 apud Cruz, 2017, p. 43-44).

Aprendemos que o historiador não pode deixar sua fonte falar sozinha, mas, nesse caso, o documento ilustra muito bem o que as normativas aqui analisadas queriam dizer com registrar e informar quando solicitado.

Organograma 1: Estrutura administrativa da Casa de Correção - 1896

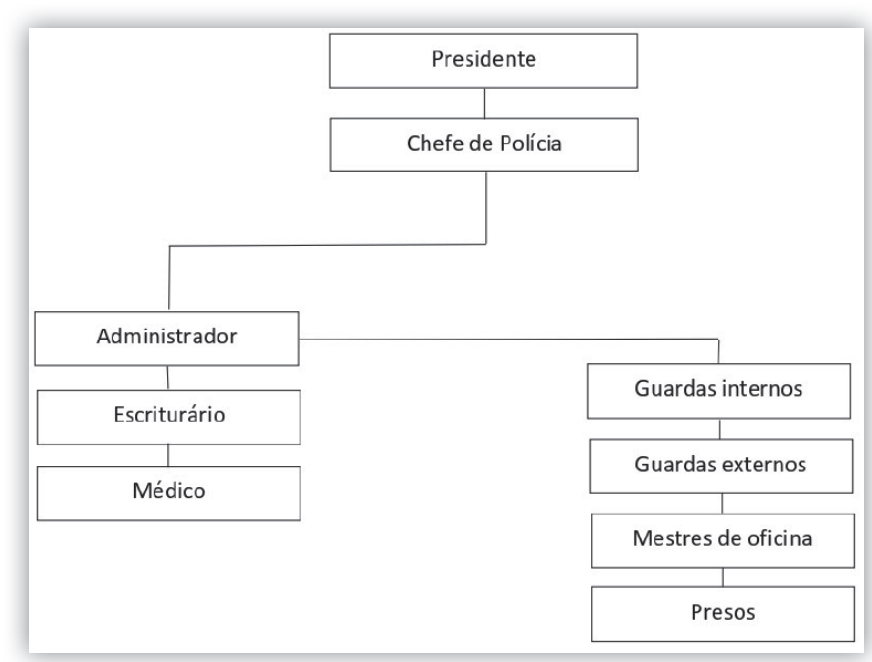

Fonte: Leis, decretos e atos do Governo do Estado do Rio Grande do Sul, 1896. Porto Alegre: Oficinas Gráficas d’A Federação, 1926, p. 317-344, L-627. 
Conforme o Organograma l, o administrador, o médico e o escriturário eram nomeados pelo presidente do estado, a partir de indicações do chefe de Polícia, ${ }^{20}$ mas o primeiro estava "imediatamente subordinado" a este último, "com quem se corresponderá diretamente". ${ }^{21}$ E, internamente, assumia o administrador todas as prerrogativas como o "chefe superior de todos os empregados do estabelecimento". ${ }^{22}$ Acrescente-se a isso o direito que gozava em relação à contratação dos guardas internos, ${ }^{23}$ permitindo-lhe montar sua própria prisão, com gente de sua confiança. E, quando novos cargos iam sendo criados para suprir as demandas da prisão, também ele estava incumbido de informar os nomes daqueles que deveriam ocupá-los (veja-se o Organograma 2). A guarda externa era militar e incumbia-se da vigilância dos portões da Correção.

Por outra parte, é importante observar que, além do trabalho, nenhuma outra disposição se reservou, no regulamento de 1896, para a escolarização e a atenção religiosa destinada aos condenados, embora ambos elementos fossem extremamente caros à cartilha disciplinar defendida por não poucos reformadores e, desde finais do século XIX, chancelada nos Congressos Penitenciários.

Se, num primeiro momento, a falta de interesse pelos frutos advindos de uma ação espiritual poderia ser hipoteticamente atribuído à influência do positivismo e da recente separação entre Igreja e Estado, o mesmo não justificaria o descaso em relação à educação primária. E, se bem é verdade que se fez menção a uma sala de leitura e a possível constituição de uma biblioteca, essas somente estariam à disposição dos presos de "melhor nota". ${ }^{24}$

Caso constituída, essa biblioteca deveria conter "livros de leitura amena e edificante para o uso dos presos, segundo os graus de inteligência e disposições morais de cada um", ${ }^{25}$ e a leitura poderia ser "feita por empregado designado pelo administrador, em voz alta acompanhada de instruções familiares àqueles que não poderem aproveitá-las individualmente". ${ }^{26}$

Deve-se dizer, com perspectiva, que alguns anos depois, reservou-se espaço na Casa de Correção para uma escola, mas regulamentariamente falando, a referência veio apenas no conjunto normativo de 1913, conforme se pode verificar a partir da inserção de um "professor" no quadro de servidores, conforme o Organograma 2. Da mesma forma, será nessa

\footnotetext{
${ }^{20}$ Artigo 7 do regulamento de 1896.

${ }^{21}$ Artigo 13 do regulamento de 1896.

${ }^{22}$ Artigo 12 do regulamento de 1896.

${ }^{23}$ Artigo 8 do regulamento de 1896 .

${ }^{24}$ Artigo 170 do regulamento de 1896.

${ }^{25}$ Artigo 171 do regulamento de 1896.

${ }^{26}$ Artigo 172 do regulamento de 1896.
} 
atualização do selo normativo-correcional que se poderá ver a importância dada às atenções e cuidados espirituais. Vale um último comentário sobre essa questão.

Organograma 2: Estrutura administrativa da Casa de Correção - 1913

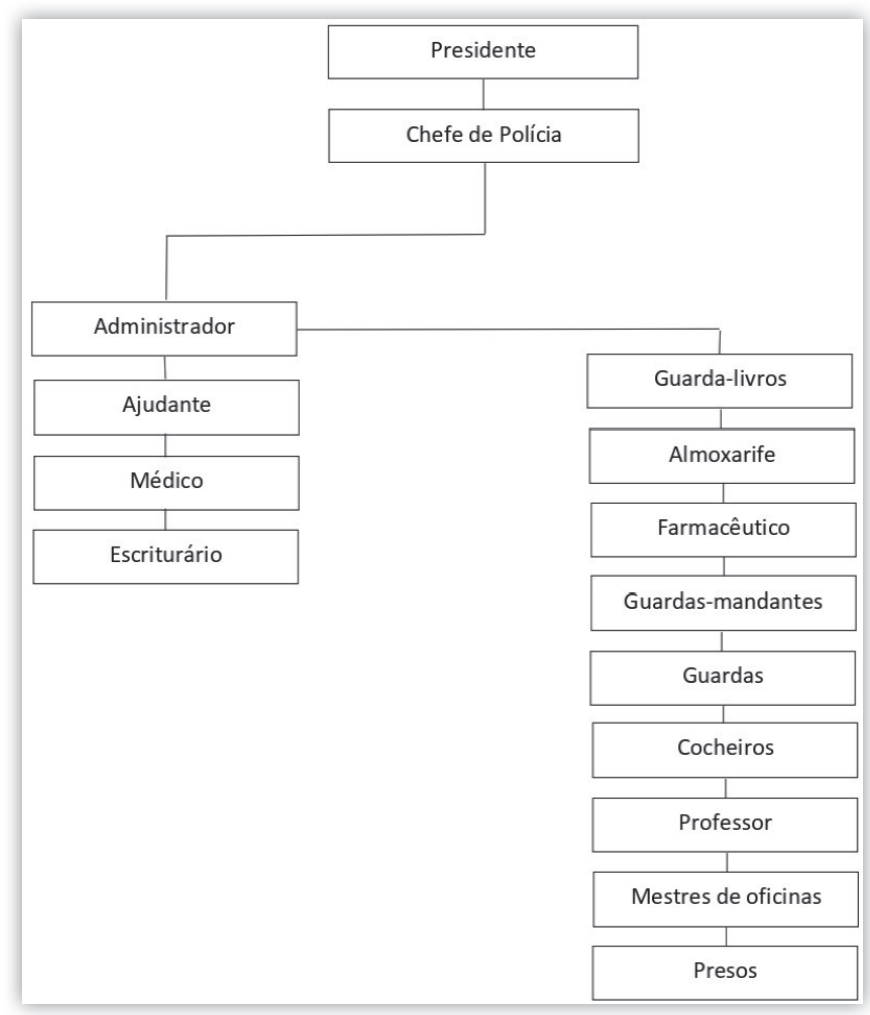

Fonte: Arquivo Histórico do Rio Grande do Sul, SIE [Secretaria de Interior e Exterior], L-0653.

Por mais que o articulado destinado à normatização das práticas religiosas no recinto penal facultasse aos presos liberdade de escolha, foi a Igreja católica a instituição mais fortemente presente, e, apesar das tentativas de outras denominações, será a que aumentará exponencialmente durante os anos 1920 sua ação entre os encarcerados, participando tanto das celebrações civis como das eclesiásticas promovidas no intramuros carcerário.

Devido à proposta e por questão de espaço, não será possível analisar aqui essas práticas, mas vale dizer que elas se irmanavam e tinham como objetivo a emenda dos sentenciados e o fortalecimento do catolicismo no estado. A atenção religiosa e ideológica dispensada aos reclusos da Casa de Correção de Porto Alegre deve ser compreendida dentro de um processo maior de recatolização do Rio Grande do Sul (Isaia, 1998), que buscava fazer frente a um 
só tempo ao desgaste secular da sua imagem, à concorrência de outras denominações religiosas, especialmente as protestantes, e ao perigo das ideias marxistas e modernas num sentido amplo (Mainwaring, 1989, p. 43).

\section{As republicanas oficinas da Casa de Correção}

A velha Cadeia Civil de Porto Alegre terminou os seus dias imperiais albergando aproximadamente quatro centenas de encarcerados e apresentando um quadro de misérias há tempos conhecido de perto não somente pelos presos, mas também por civis e autoridades governamentais (Cesar, 2015, p. 12-25). Lembre-se que o próprio Júlio de Castilhos integrou, em 1885, uma comissão que realizara uma visita ao estabelecimento, descrevendo-o como uma "inquisitorial prisão". Os problemas, portanto, não eram poucos.

Como vimos, urgia a necessidade de um local para o cumprimento da pena de prisão com trabalho ${ }^{27}$ e na qual se privasse de liberdade respeitando o regime de isolamento celular,,$^{28}$ ao mesmo tempo que havia de se fazer frente ao aumento de reclusos que, em 1903, quase alcançou as sete centenas (veja-se o Gráfico l), e, consequentemente, os gastos carcerários produzidos.

Assim, entre 1895 e 1896, organizaram-se e implementaram-se as primeiras oficinas, que também auxiliaram, certamente, a dar vazão às tensões típicas de recintos fechados com grande aglomeração humana. ${ }^{29}$ Em matéria de 1907 já se felicitava ao então administrador pelo zelo com o edifício. Asseio, luz, ar, assoalhos caprichosamente limpos, substituição das lages pelo calçamento com mosaicos, assim como do piche que existia em "altas barras" por todas as partes pela cal, davam outra cara ao velho estabelecimento prisional. Dizia-se que, além do "aspecto animador de claridade, retirando da vista a triste impressão da negridão", evitava-se também o "incommodo que produz aspirar as emanações do piche", restando ainda eliminá-lo de algumas portas de xadrezes.

A isso o articulista acrescenta a reutilização de velhos encanamentos para a fabricação de escarradeiras "bem feitas", a disponibilização de uma sala no térreo do edifício para que

${ }^{27} \mathrm{Na}$ Casa de Correção de Porto Alegre, a pena de prisão com trabalho será cumprida, segundo Borges de Medeiros, atendendo às "gradações ou differenças que exigem as disposições organicas dos criminosos" (Medeiros, 1903, p. 6). Ou seja, da mesma forma que as "penas não correspondiam ao crime, mas à classificação dos criminosos feita pelos peritos e ao comportamento apresentado pelo preso na prisão” (Santos, 2009, p. 307).

${ }^{28} \mathrm{O}$ artigo $4^{\circ}$ do regulamento de 1913 rezava: "Tanto quanto permitirem as condições atuais do estabelecimento, será observado em relação aos condenados o regime de isolamento celular para comer e dormir, e de trabalho comum durante o dia, sob o regime do silêncio".

${ }^{29}$ Conforme o artigo 45 do regulamento de 1913, três eram as recomendações acerca das oficinas: 10) deviam ser de fácil e curta aprendizagem; $2^{\circ}$ ) isentas de qualquer causa de inabilidade; e $3^{\circ}$ ) deviam atender a maior produtividade possível. 
os advogados pudessem atender aos seus clientes, e o abundante abastecimento de água, "distribuído por grandes tanques bem cobertos onde não penetram as poeiras". A cozinha, como todo o recinto, não poderia oferecer "maior limpeza", sendo a alimentação dos presos "preparada e fornecida com generos de primeira qualidade" (A Federação, 12 mar. 1907, p. 1).

As melhorias e modernizações continuaram nos anos subsequentes. Em 1909, o estabelecimento foi dotado de rede de esgotos e iluminação elétrica próprias (Gonçalves, 1909, p. 10). Em mensagem de 1914, deu-se conta da instalação de uma usina elétrica, em substituição ao antigo sistema de iluminação a gás. A usina servia para acionar quatro motores, com capacidade para iluminar dois quartéis (Medeiros, 1914, p. 16). Em 1917, devido à "superpopulação", levou-se a cabo a construção de um terceiro pavimento com acomodações para, aproximadamente, outros cem reclusos (Medeiros, 1917, p. 17 e 26). Um paliativo, certamente, mas muito longe de suprir a demanda de espaços e nem há o que dizer em relação à necessidade de atender ao regime celular. Por certo, em 1921 o edifício contava com noventa células, das quais apenas 74 eram ocupadas pelos presos. Nas restantes, distribuíam-se as instalações da farmácia, gabinete dentário, enfermaria, barbearia, escola etc. (Medeiros, 1921, p. 20).

\section{Gráfico 1: Flutuação da população carcerária da Casa de Correção (1892-1930)}

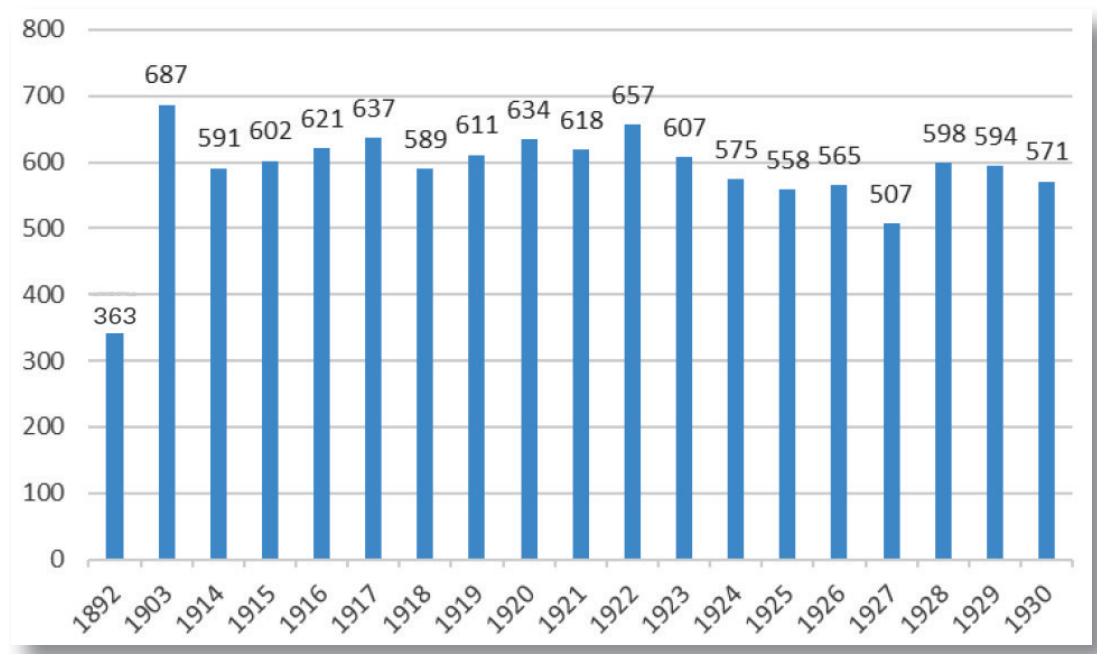

Fonte: Mercantil: Folha da Tarde, 2 jan. 1893, p. 2; Medeiros, 1904, p. 17; Machado, 1915, p. 10; 1916 p. 5; Medeiros, 1917, p. 17; 1918, p. 10; 1919, p. 10; 1920, p. 35; 1921, p. 2O; 1922, p. 12; 1923, p. 20; 1924, p 10; 1925, p. 21; 1926, p. 8; 1927, p. 28; Vargas, 1928, p. 39; 1929, p. 34; 1930, p. 81; A Federação, 8 set. 1931, p. 5 
Mas o grande logro dos castilhistas foi realmente promover o êxito das oficinas da Casa de Correção. Albergando uma população essencialmente masculina ${ }^{30}$ e solteira, ${ }^{31}$ com consideráveis índices de analfabetismo, ${ }^{32} \mathrm{o}$ trabalho, ademais de moralizador e lucrativo, também agia como uma válvula de escape das tensões intramuros.

Decerto, ao menos desde 1900, as oficinas já estavam dando lucro. A renda apurada até maio daquele ano, por exemplo, alcançou 16:401\$580 réis, fruto do trabalho realizado nas oficinas de marcenaria, chapelaria, sapataria, alfaiataria, ferraria e fotográfica (Medeiros, 1900, p. 16-17). Não é de estranhar, portanto, que a partir de então a Casa de Correção passasse a ser apresentada como um "estabelecimento modelo" (Medeiros, 1903, p. 6).

Tampouco é preciso demorar-se muito nos valores da Tabela l, para saltar à vista que, a partir de 1926, se superou os duzentos contos anuais de "lucro líquido", como se dizia, deduzidas as despesas com o "respectivo custeio". Apenas para se fazer uma ideia do montante, o primeiro prêmio da Loteria do Estado do Rio Grande do Sul, "em benefício de Casas de Caridade e estabelecimentos Pios”, noticiado em novembro de 1926, era de 100:000\$000 (A Federação, 25 nov. 1926, p. 5), ou seja, menos da metade do lucro auferido pelas oficinas somente naquele ano.

Todo esse êxito econômico do trabalho penal demonstra, contrariando a análise foucaultiana, como os governantes sul-rio-grandenses não privilegiaram apenas a "constituição de uma relação de poder", ou, de "um esquema da submissão individual e de seu ajustamento a um aparelho de produção" (Foucault, 2012, p. 230). Além disso, também focaram, talvez com maior afinco, na possibilidade real de lucro. É importante recordar que, no século XIX, o fechamento das oficinas foi justificado pela despesa que ocasionava e não porque o processo de emenda hipoteticamente por elas proporcionado não funcionasse. Assim como para os governantes imperiais, a utilidade do trabalho penal não podia redundar apenas numa "forma econômica vazia", tinha que dar lucro!

Por outra parte, como atentaram Rusche e Kirchheimer (2004), é claramente perceptível o paralelismo em relação à nova aposta pela implantação do trabalho penal por meio de oficinas, e a conjuntura econômica experienciada pelo Brasil em geral, e pelo estado do Rio Grande do Sul em particular, principalmente no que diz respeito ao processo de industrialização. ${ }^{33}$ O recorte cronológico em tela compreende justamente esse período de desenvol-

\footnotetext{
30 Em 1918 (576 homens e 13 mulheres); 1919 (600 e 11); 1920 (624 e 10); 1922 (641 e 16); 1923 (593 e 14); 1924 (563 e 12$) ; 1925$ (544 e 14); 1926 (553 e 12); 1928 (588 e 10); 1929 (481 e 13); 1930 (557 e 14). Os dados dessa e das duas notas seguintes foram compilados das mesmas fontes referenciadas no Gráfico 1

${ }^{31}$ Em 1918 (363 solteiros, 180 casados, 46 viúvos); 1922 (459, 160, 37); 1926 (376, 145, 44); 1929 (348, 172, 74); 1930 (359, 188, 24).

321918 (37\%); 1922 (22\%); 1923 (29\%); 1926 (24\%); 1929 (21\%); 1930 (17\%).

${ }^{33}$ Conforme Bodea, a "partir do final do século XIX surge um parque industrial mais diversificado no Rio Grande do Sul. De acordo com o Censo de 1907 o Rio Grande era a terceira unidade da Federação em termos de produto industrial, responsável por 15\% da produção manufatureira do país, contra 16\% gerados em São Paulo e 33\% no Distrito Federal".
} 
vimento industrial que, ademais de requerer a formação de uma massa operária, pedia que ela fosse também reprodutora da concepção ideológica burguesa de trabalho vigente. O que, acrescente-se, não impedia, certamente, que o trabalho penal fosse usado pelos administradores penitenciários e visto por muitos condenados, e talvez mais incisivamente em determinados momentos que em outros, como uma forma severa de punição.

Nas oficinas republicanas da Casa de Correção o trabalho desenvolvido pelos encarcerados chegou a ter um caráter fortemente competitivo graças às modernizações do recinto e da introdução de maquinário. Já em 1901, uma comissão composta por Fernando Mothes, João Birnfeld e Bernardo Boecker, solicitou uma menção honrosa para os chapéus de palha de coco manufaturados pelos presos, durante a Exposição Estadual daquele ano (A Federação, 20 abr. 1901, p. 2). Na seção de móveis da mesma exposição, a Correção foi indicada pela comissão formada por Adam Hoffmann, João Baptista da Silva e Carlos Goeden, ao segundo prêmio por duas secretárias (18 maio 1901, p. 2). ${ }^{34}$ E na Exposição Nacional de 1908, recebeu como prêmio - na seção de "Varias Industrias" - uma medalha de prata, concorrendo no Grupo 44, por "obras de serralheiro" (24 abr. 1909, p. 1).

Desacreditada enquanto instituição correccional há pelo menos quarenta anos, o êxito econômico e os prêmios recebidos pelos produtos elaborados pelos presos não seriam, evidentemente, desdenhados pela imprensa castilhista. Apesar de contas, eram a prova material e simbólica da eficiência do governo do estado e de sua política modernizante. Um autêntico triunfo da ordem e senha do progresso sob o regime republicano.

Tanto é assim que a façanha de 1901 é relembrada, aproximadamente seis anos depois, em um extenso artigo. Neste texto, segundo o articulista, "o visitante, ao penetrar o alteroso portão da Casa de Correcção impressiona-se bem desde logo, ouvindo o ruido dos instrumentos de trabalho nas officinas que se estendem à direita e esquerda, sentindo vibrar a trepidação produzida pelos motores a vapor". No gabinete da administração, além dos retratos de Júlio de Castilhos e Borges de Medeiros, outras "photographias e varios quadros emmoldurados contendo os diplomas conferidos pelo jury da Exposição à Casa de Correcção" ocupavam, garbosamente, lugar de destaque.

Ainda segundo o autor, o "Estado possuía então a mais alta porcentagem nacional de firmas industriais de propriedade individual, o maior número de bancos controlados por capitais nacionais e o maior índice de investimentos norteamericanos". E conclui afirmando que a expansão industrial deu-se, "em parte, às custas de uma intensificação da exploração da força de trabalho: a jornada média de trabalho situa[va]-se entre 10 e 12 horas diárias nas fábricas, oficinas e construção civil; no comércio tem-se notícia de jornadas de trabalho ainda mais prolongadas", e o "trabalho feminino e infantil percebia uma remuneração ainda mais baixa do que o trabalho operário adulto" (Bodea, s.d., p. 24-25).

${ }^{34}$ As comissões eram nomeadas pelo presidente do estado. Na ocasião, o prefeito José Montaury ocupava a presidência da comissão da Exposição (A Federação, 18 maio 1901, p. 2). 
Tabela 1: Lucro auferido pelas oficinas

da Casa de Correção (1900-1930)

\begin{tabular}{|c|c|c|c|c|c|}
\hline ANO & VALOR & ANO & VALOR & ANO & VALOR \\
\hline 1900 & $16: 401 \$ 580$ & 1911 & $77: 843 \$ 760$ & 1922 & $191: 302 \$ 019$ \\
\hline 1901 & $10: 712 \$ 020$ & 1912 & $124: 049 \$ 410$ & 1923 & $168: 314 \$ 558$ \\
\hline 1902 & $11: 071 \$ 180$ & 1913 & $126: 448 \$ 045$ & 1924 & $168: 314 \$ 558$ \\
\hline 1903 & $14: 748 \$ 382$ & 1914 & $103: 167 \$ 544$ & 1925 & $183: 054 \$ 854$ \\
\hline 1904 & $22: 323 \$ 578$ & 1915 & $129: 637 \$ 819$ & 1926 & $240: 922 \$ 419$ \\
\hline 1905 & $15: 975 \$ 706$ & 1916 & $101: 475 \$ 471$ & 1927 & $233: 568 \$ 321$ \\
\hline 1906 & $33: 107 \$ 860$ & 1917 & $164: 899 \$ 967$ & 1928 & $264: 632 \$ 415$ \\
\hline 1907 & $49: 822 \$ 120$ & 1918 & $172: 897 \$ 384$ & 1929 & $204: 214 \$ 282$ \\
\hline 1908 & $36: 981 \$ 830$ & 1919 & $89: 084 \$ 381$ & 1930 & $232: 257 \$ 978$ \\
\hline 1909 & $82: 723 \$ 830$ & 1920 & $128: 970 \$ 844$ & & \\
\hline 1910 & $25: 471 \$ 810$ & 1921 & $121: 478 \$ 954$ & & \\
\hline
\end{tabular}

Fonte: Medeiros, 1900, p. 17; 1903, p. 6; 1904, p. 17;1906, p. 7; 1907, p. 9; 1914, p. 16; Machado, 1915, p. 10; 1916, p. 5; Medeiros, 1917, p. 17; 1918, p. 10; 1919, p. 11; 1920, p. 36; 1921, p. 20; A Federação, 8 set. 1931, p. 5; Jornal do Commercio, 24 jun. 1916, p. 1.

Ainda conforme o articulista, que certamente conhecia muito bem o estabelecimento, no "salão da secretaria" se podia ver uma "mobilia finissima", composta de 15 peças em louro, estofada, com as respectivas capas, tudo feito pelas mãos dos sentenciados, destinada à sala principal do Hospício de São Pedro. Se em termos de qualidade, como se disse, a dita mobília "nada deixa a desejar", não se rasgou menos elogios para os calçados manufaturados nas ditas oficinas: "São muito de notar os calçados feitos na respectiva officina, quer o que ha de mais elegante em calçado para senhoras, quer para homens". O resultado, portanto, não poderia ser outro: "Os serviços de tal officina já estão sendo aproveitados por encommendas de proprias fabricas, pois a sua qualidade, feitura e custo determinam certamente a devida procura" (A Federação, 12 mar. 1907, p. 1).

Antes de seguirmos adiante, vale quebrar um pouco a narrativa periodística para lembrar justamente que ela está a serviço do regime castilhista. Essas descrições minuciosas, a partir de visitas realizadas ao recinto penal, acabavam por invisibilizar tudo aquilo que fugia à imagem de ordenamento e eficácia administrativa. Pode-se, inclusive, incluí-la dentro daquela categoria de impressões de visitantes analisadas por Salla para a Penitenciária do Estado de São Paulo, inaugurada em 1920. Segundo o pesquisador, 
os visitantes que se detinham à porta de uma oficina ao ver os presos trabalhando curvados sobre a sua tarefa, silenciosos [...] não imaginavam a freqüência das brigas que ali poderiam ocorrer, os pequenos furtos de material e de instrumentos, as amarguras que não se externavam. O governo do estado cultivava sua criatura com zelo e todo visitante que passasse pela cidade, renomado ou não, incluía no seu roteiro a visita à Penitenciária. Essas meteóricas passagens cumpriam seu papel de levarem consigo uma impressão superficial, esvaziada dos dramas que a prisão abarcava, e também ainda de deixarem um rastro de elogios pela imprensa (Salla, 2006, p. 298).

E, quando não se comercializava, nem se ganhavam prêmios, ainda assim se requeriam os braços da Correção, como para a feitura dos móveis de apoio/base dos produtos da indústria rio-grandense, levados a exposições de fora do estado. Em uma delas, organizada no "Salão principal do Museu Commercial", no Rio de Janeiro, as manufaturas estiveram "sobre mesas e pyramides de madeira de lei, confeccionadas pelos presos da Casa de Correção de Porto Alegre, expressamente para figurar neste certamen" (A Federação, 30 maio 1907, p. 1). ${ }^{35}$ A princípios de novembro desse ano, no prédio no 20 da rua Marquês de Olinda, centro da capital pernambucana, também se montou uma exposição de produtos industriais rio-grandenses em "vitrines horisontaes e verticaes; mesas redondas, quadradas, hexagonaes e octogonaes; estantes; etagéres; cantoneiras; columnatas etc. etc. [...] trabalhadas com bastante gosto na Casa de Correcção de Porto Alegre" (6 nov. 1907, p. 1).

Sabe-se, ainda, que suas oficinas também foram requisitadas para a substituição dos móveis em "máo estado" existentes no "Tribunal", "que datam da sua primeira installação" (Machado, 1915, p. 7). Anos antes, o mobiliário escolar adquirido para o estado havia sido "quasi todo fornecido" pela Casa de Correção, "vindo apenas uma diminuta fracção dos Estados Unidos" (Gonçalves, 1911, p. 12; 1912, p. 15).

Além dos objetos já listados, desconfiamos que os uniformes dos presos também podiam estar sendo confeccionados dentro do estabelecimento, uma vez que se compravam além de madeiras de "diversas qualidades" para a oficina de marcenaria e carpintaria, "fazendas para o vestuario dos reclusos" (A Federação, 21 dez. 1923, p. 7).

Quanto à especialização propriamente dita das oficinas, sabemos pelos regulamentos que a ideia era, em 1896, abrirem quatro, a saber: sapateiros, carpinteiros, canteiro e chapeleira. ${ }^{36}$ Em mensagem de 1898, fez-se referência ao funcionamento de "tres officinas", sem discriminá-las, e, em 1900, confirmava-se a existência de seis: marcenaria, chapelaria, sapataria, alfaiataria, ferraria e fotográfica (Medeiros, 1898, p. 22; 1900, p. 16). Segundo o regu-

\footnotetext{
${ }^{35}$ Reportagem publicada originalmente na Tribuna, do Rio de Janeiro, de onde fora transcrita.

${ }^{36}$ Artigo 61 do regulamento de 1896.
} 
lamento de 1913, o número se elevaria a oito: artes gráficas, serralheria, marcenaria e carpintaria, sapataria, alfaiataria, telas de arame, mosaicos, e padaria. ${ }^{37}$

A mensagem presidencial daquele mesmo ano referiu-se a nove oficinas e uma usina elétrica, sendo "a mais importante" delas a de serralheria, individualmente responsável pela venda de 110:309\$240 réis (Medeiros, 1913, p. 15). Os bons ventos do ano de 1913 arrefeceram em 1914, já que o lucro foi bem menor (veja-se a Tabela 1), segundo se publicou, devido ao "retrahimento das transações com as praças do Norte e a elevada alteração dos preços da materia prima" (Machado, 1915, p. 10). No entanto, o revés foi passageiro, uma vez que, em 1915, a economia parece ter girado bem para a Correção, tendo em vista os dividentos computados para aquele ano, graças em grande parte à importação dificultada pela guerra. Conforme a prestação de contas, houve um aumento nos "saldos" em todas as oficinas, excepto na de tipografia que deu um "pequeno deficit" (Machado, 1916, p. 5).

A essa altura, a Correção tinha-se tornado uma fábrica de relevo, alcançando, além do Rio Grande do Sul, mercados longínquos para seus produtos, tal como podemos observar na Figura 1, onde aparece gravado "Santos S. Paulo" nos caixotes preparados na seção de empacotamento e encaixotamento da oficina de serralheria. Não é mera coincidência, portanto, que o ano de produção da fotografia seja o mesmo da mensagem em que a referida oficina é avaliada como "a mais importante" (Medeiros, 1913, p. 15). Mas Santa Catarina, Paraná, Rio de Janeiro, Minas Gerais e Pernambuco também devem ser incluídos entre as praças consumidoras (Jornal do Commercio, 24 jun. 1916, p. 1).

A fórmula do sucesso daquela oficina, sem querer desmerecer o suor dos apenados, parece que residia numa parceria entre o estabelecimento e industriais da cidade. Desde 1910 havia um contrato com a empresa de Pedro Wallig, "a qual dá a entender o administrador Frederico Ortiz em relatório de 1916, fora responsável pela implantação de novas ferramentas e aperfeiçoamento do ofício entre os presos" (Cesar, Szczepaniak, 2019, p. 303). Ainda segundo os autores,

o resultado dessa especialização técnica não tardou em se notar na área produtiva, a ponto de Ortiz não recomendar a renovação do contrato, embora reconhecesse que "a firma contractante muito tenha se esforçado para o desenvolvimento dessa officina, tornando-a em pouco tempo a primeira do estabelecimento, como também do Estado" (Cesar, Szczepaniak, 2019, p. 303).

Tanto sucesso fez aparecer por esse período as primeiras críticas de competição desleal com o trabalho livre, ao menos registradas oficialmente, apesar de algumas reportagens insistirem,

${ }^{37}$ Artigo 46 do regulamento de 1913 
ademais da própria administração, quanto ao cuidado em "não fazer à industria particular uma concurrencia que a esta possa prejudicar" (Jornal do Commercio, 24 jun. 1916, p. 1).38

No ano de 1915, em relatório ao Secretário de Negócios do Interior e Exterior, o administrador da prisão chegou a registrar queixas apresentadas pelos industriais da cidade, embora as considerando infundadas. Segundo o máximo funcionário, os queixosos alegavam que os preços baixos dos produtos produzidos pelos presos em obras de idêntico acabamento que as suas thes reduzia os lucros (Cesar, Szczepaniak, 2019, p. 300-301).

Na matéria anteriormente citada, publicada no Jornal do Commercio (RJ), se disse que, para evitar tal concorrência, adotava-se nas vendas "os preços constantes dos catalogos das casas estabelecidas em Porto Alegre”, mas pelo visto, a história contada na imprensa, além de diferente, ocultava os queixumes.

Como também vimos observando, as fontes consultadas mostram uma oscilação em relação ao número de oficinas em funcionamento ao longo do período analisado, fazendo-se valer, certamente, a prerrogativa de criá-las quando julgadas "convenientes", ou de suprimi-las quando não apresentassem rendimentos. Isso também explica o contínuo vaivém de aberturas e fechamentos de oficinas, acompanhando as especializações e demandas do mercado. Entre 1916-1917, havia dez em atividade: serralheria, marcenaria, mosaicos, sapataria, telas, fotografia, padaria, alfaiataria, espelhação e gravura, e tanoaria. Delas, apenas a última não vinha "produzindo lucro" (Medeiros, 1917, p. 17).

Sobre a padaria, registrou-se como um "facto curiosissimo" (Correio da Manhã, 7 jan. 1920, p. 2) o fornecimento de pão à população porto-alegrense, durante a greve dos padeiros, em maio de 1919, por cerca de seis dias. Além da clara tentativa de desmobilizar o movimento sabotando a falta de fabrico e distribuição de pão na capital do estado, ${ }^{39}$ cabe acrescentar

\footnotetext{
${ }^{38}$ Segundo Melossi e Pavarini, em seu clássico Cárcere e fábrica, os protestos e agitações contra a produção penitenciária nos Estados Unidos continuaram até por volta de 1930, embora o problema da competência entre a produção penal ea livre já tivesse praticamente arrefecido a finais dos Oitocentos. Segundo os autores, as razões do fenômeno eram duas: as "dificuldades crescentes encontradas pelo capital privado para industrializar o processo produtivo penitenciário em formas que ainda pudessem ser competitivas num momento de renovação tecnológica no mundo da produção livre" e o "crescente peso das organizações sindicais na vida política e econômica dos Estados Unidos" (Melossi, Pavarini, 2006, p. 206-207). Pelo visto, no caso porto-alegrense, foi o Estado que assumiu o processo de modernização técnica e profissional, ao menos para algumas oficinas, impedindo qualquer intervenção externa duradoura, ademais de blindá-las contra possíveis críticas ou ataques do extramuros durante o período em análise, demonstrando assim "a inter-relação entre os níveis econômico e político [...] dado o predomínio da ideologia positivista na atuação dos elementos do Partido Republicano Rio-grandense, ao contrário do que se dava na esfera federal, onde predominavam as idéias do liberalismo clássico" (Reichel, 1980, p. 11).

39 Talvez não seja forçado associar esse ato do governo do estado a uma reação à greve de 1917, ainda viva certamente na memória das autoridades. Naquela ocasião, os padeiros foram das primeiras categorias a aderirem à greve ao lado de tipógrafos, pedreiros, carpinteiros e tecelões. Consta, inclusive, que na "Praça Garibaldi grupos de padeiros chega[ra]m a distribuir pão de graça aos 'miseráveis"' (Bodea, s.d., p. 33-34).
} 
que o fornecimento já vinha sendo realizado regularmente ao Colégio Militar e hospitais, ademais, claro, do consumo interno (Szczepaniak, 2004, p. 84).

O que se passava naquele estabelecimento encravado na antiga Ponta do Arsenal também chamava a atenção em outras paragens. Reproduzindo trechos da mensagem de Borges de Medeiros, o jornal Cittá di Caxias, em janeiro de 1918, além de fazer referência ao seu "movimento industrial", listou as dez oficinas em atividade: serralheria, marcenaria, alfaiataria, fotografia, mosaicos, padaria, tanoaria, sapataria, espelhação e gravuras, e telas (Città di Caxias, 25 jan. 1918, p. 1).

Figura 1: Detalhe da "Seção de empacotamento e encaixotamento" da oficina de serralheria da Casa de Correção (1913)

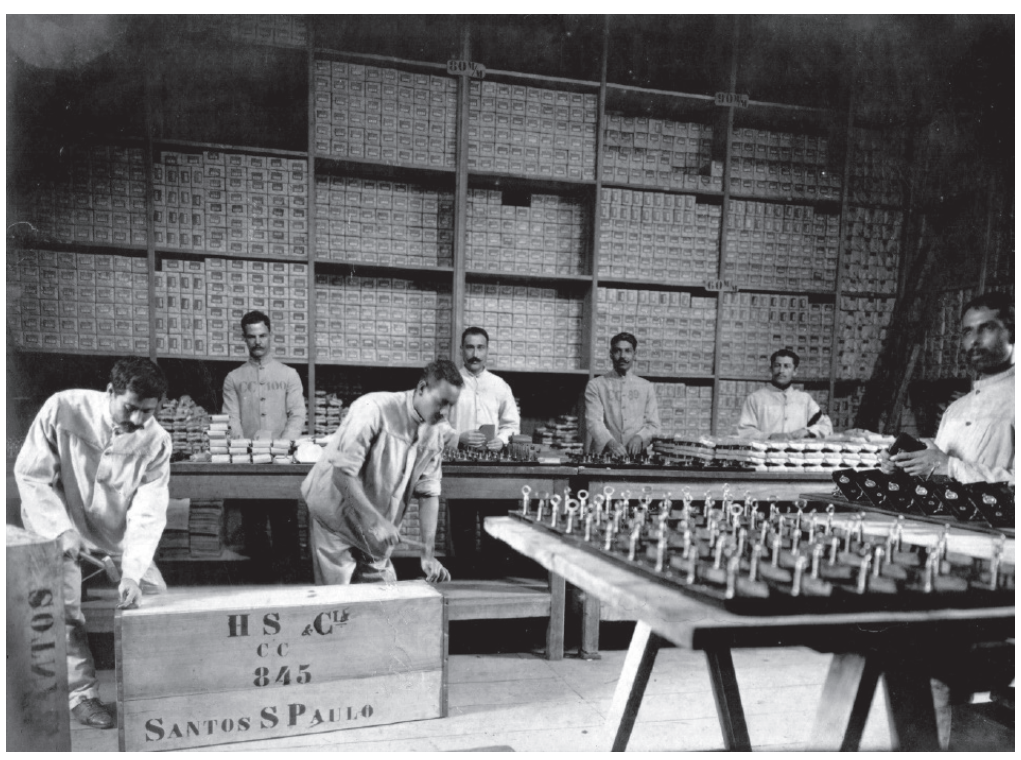

Fonte: Museu Júlio de Castilhos, imagem n. 9738.

Nesse ano, empregaram-se "em trabalhos diarios nas diferentes officinas do estabelecimento 400 reclusos e, como desses apenas 250 eram profissionaes antes da reclusão, ${ }^{40}$ segue-se que os outros só ali vão fazer a aprendizagem de uma arte ou officio que depois na

\footnotetext{
${ }^{40}$ Desconfiamos que havia por parte da administração uma espécie de triagem a partir das informações coletadas durante o ingresso dos sentenciados no estabelecimento. Poderia-se, nesse sentido, trabalhar com uma hipótese bastante plausível de que haveria certa preferência por aqueles indivíduos que já possuíam algum tipo de experiência profissional ou especialização prévia. De resto, as fontes consultadas não permitem maiores constatações ou aprofundamentos acerca desses homens que ingressavam com formação, e, portanto, aptos a serem naturalmente absorvidos pelas lucrativas oficinas da Correção.
} 
vida egressa lhes servirá para o grangeio honesto da subsistencia” (Medeiros, 1918, p. 10). Observações como essa nos fazem pensar que as máximas autoridades republicanas pareciam comungar da sensação de se ter realizado um sonho antigo, pois, ademais de lucrativas, as oficinas penitenciárias estavam formando trabalhadores, ou, quem sabe, mais do que isso, operários!

É, nesse sentido, muito sintomático que, na prestação de contas sobre a distribuição do dinheiro lucrado em 1920, entre a parte destinada ao Estado (40\%) e às custas dos processos (20\%), se fizesse menção à cota dos "operarios das officinas" (40\%) (Medeiros, 1921, p. 20). Mas não se engane, a nomeclatura não era nova, já estava em uso no regulamento de 1896, quando no artigo 68 se estipulou que, "conforme a diligência e boa vontade dos operários, o mestre da oficina lhes dará cartões de prêmios, o que dará lugar a recompensas, a juízo do administrador".

Observa-se que, conforme se passavam os anos e com eles introduziam-se melhorias técnicas e especializações, também o número de presos-operários aumentava. Cifras mais antigas, retiradas dos Relatórios da Secretaria de Negócios do Interior e Exterior, mostram oscilações, mas são contundentes em relação ao contínuo aumento do número de encarcerados empregados nas oficinas. Nem bem raiado o século XX, as oficinas mantinham ocupados bem mais de uma centena de indivíduos privados de liberdade, superando as duas centenas em 1903, e contabilizariam 267 em 1904 (Pedroso, 2003, p. 115). Nas décadas seguintes, seriam por volta de 400 os presos empregados.

Mas mesmo com farta mão de obra disponível, havia de se manter o foco. Como já se chamou a atenção, fechar oficinas fazia parte da estratégia de seguir o fim econômico sobre qual discorreu longamente Mario Guedes, em seu artigo citado, republicado em 28 de janeiro de 1920. Nesse texto, Guedes fez referência a dez oficinas e concluía a lista com um "etc.": serralharia, marcenaria, mosaicos, tela, sapataria, padaria, colchoaria, alfaiataria, empalhadores, e tanoaria. Seguindo a cartilha economicista, naquele mesmo ano se destacou a desenvoltura produtiva da serralheria e marcenaria, ao mesmo tempo que se informou a supressão daquelas que não logravam decolar, a saber, as oficinas de vime, espelhação e gravura, e fotografia (Medeiros, 1920, p. 36).

Com efeito, poucos meses depois, as máquinas e materiais pertencentes às extintas oficinas de espelhação e gravuras, e de tipografia, sairiam em leilão, esta última ainda em 1919 (A Federação, 6 jul. 1920, p. 8; 30 out. 1919, p. 8). A finais desse mesmo ano, sabemos por outros editais de fornecimento de materiais e ferramentas que as oficinas de marcenaria, serralheria, alfaiataria, sapataria, mosaicos, tela, e padaria continuavam funcionando de vento em popa (18 dez. 1920, p. 9).

Nos anos subsequentes, mencionou-se apenas a existência de trabalho ininterrupto nas seguintes oficinas: serralheria, marcenaria, carpintaria, alfaiataria, sapataria, mosaicos, pa- 
daria e telas de arame (Medeiros, 1922, p. 13; 1927, p. 28; Vargas, 1930, p. 82). E, se é verdade que os números não mentem, basta olharmos novamente para a Tabela 1 , a fim de nos certificarmos do aumento significativo do lucro líquido amealhado pelas ditas oficinas, desde o raiar dos anos 1920 até o seu ocaso. ${ }^{41}$

\section{Considerações finais: Afinal de contas, a Casa de Correção corrigia?}

Afirmamos linhas atrás que as autoridades republicanas gaúchas pareciam comungar de uma mesma percepção de êxito acerca do sistema penitenciário da Casa de Correção de Porto Alegre; primeiramente, graças ao avultado lucro auferido pela venda dos produtos confeccionados pelos sentenciados, mas também pela capacitação de uma mão de obra especializada e desejosamente submissa. Em mensagem de 1900, Borges de Medeiros disse que "seu aperfeiçoamento continuo a tem tornado um estabelecimento de primeira ordem. Amoldada quanto possivel [...] ao systema penitenciario do Codigo em vigor, a pena de prisão com trabalho ali encontra cabal execução" (A Federação, 27 nov. 1900, p. 1).

Outras variantes dessa fórmula mostram, não obstante, como se equacionava lucro e abatimento de custos, como se fossem sinônimos de regime penitenciário, em vez de enfatizar o trabalho, no sentido da ideologia correcional, enquanto elemento de uma penalidade (prisão com trabalho) e instrumento, como se dizia, de regeneração. Vejamos algumas palavras presidenciais ao respeito: "A productividade do trabalho augmentará cada vez mais, com proveito real para estes e compensação parcial de despesas que oneram o erario publico" (Medeiros, 1903, p. 6). "O trabalho está organisado na Casa de Correcção em condições

\footnotetext{
${ }^{41}$ As oficinas tinham orçamentos próprios e se organizavam da seguinte forma: cada oficina teria um mestre perito que dirigisse e ensinasse o ofício aos aprendizes (art. 68 do regulamento de 1913). No caso de não se dispor de mestre, a dita oficina ficaria sob a direção de um condenado designado pelo administrador (art. 69). As oficinas se organizariam em turmas de vinte presos. Caso se dispusesse de duas, a primeira seria dirigida aos aprendizes e inspecionada pelo mestre, e a segunda colocada sob a direção do preso designado para chefiá-la (art. 70). Em hipótese alguma se permitiriam turmas com mais de vinte ou menos de dez encarcerados (art. 71). Aos mestres das oficinas/turmas cabia (art. 75): 10) dirigir os trabalhos de que forem encarregados e vigiar os presos a seu cargo durante as horas de serviço, ensinar-lhes o ofício e marcar-Ihes o lugar conveniente nas oficinas; $2^{\circ}$ ) Cuidar para que as ferramentas, utensílios, matéria-prima etc. não sejam estragados pelos presos, indenizando estes o estabelecimento pela falta ou extravio que se der; 30 ) auxiliar o administrador e ajudante em tudo que se refere ao recebimento da matéria-prima, ao fabrico eà conservação dos objetos manufaturados, assim como em tudo que for concernente à distribuição, reparo ou renovação de ferramentas, utensílios etc.; 40) assinar os pedidos de ferramentas, matéria-prima e utensílios, bem como as guias de entrega dos produtos manufaturados na sua oficina; 50) dar ao administrador, ou, na sua ausência, ao ajudante, conhecimento das infrações do regulamento cometidas nas oficinas, bem assim da deterioração ou extravio de ferramentas/objetos; 60) apontar os presos que estiverem sob a sua direção, passando ao guarda-mandante a nota de presença deles, todos os dias, procedendo-se para esse fim à chamada; 70) ter a seu cargo a escrituração dos seguintes livros: lançamento diário dos trabalhos, com indicação minuciosa de natureza e quantidade dos objetos distribuídos a cada preso; lançamento de toda a ferramenta e utensílios da oficina; e apontamento dos presos que trabalharem na oficina.
} 
de real aproveitamento para os condemnados e para o Estado" (Medeiros, 1904, p. 16). E, por fim: "A occupação que se lhe dá torna menos penosa a reclusão e prepara, embora modestamente, um peculio para cada detento" (Gonçalves, 1909, p. 10).

Perceba-se aí, nitidamente, como o interesse maior se assentava antes no fim econômico do que realmente numa desejada moralização por meio da aplicação laboral. Assim como o lucro fazia abrir e manter as oficinas em funcionamento, o prejuízo, por sua vez, determinava os fechamentos. Em outras palavras, a razão de existirem não se justificava, apenas, pelo fato de constituírem espaços disciplinares voltados à emenda e preparação dos sentenciados à vida em liberdade.

Nesse sentido, vale trazer novamente à baila a matéria assinada por Mario Guedes, publicada originalmente no jornal Correio da Manhã, do Rio de Janeiro. Conforme o articulista, no "estado do Rio, por exemplo, os sentenciados de todos os seus municipios são recolhidos à penitenciaria da capital. Dá-se é que a educação profissional ahí não tem fim econômico. É penitenciaria que dá na vista, talvez. E só" (Correio da Manhã, 7 jan. 1920, p. 2). Nada mais diferente, conforme Guedes e o documentado até aqui, do que se verificava no estabelecimento penal porto-alegrense.

Vinte anos antes, uma reportagem produzida à raiz da mensagem presidencial de Borges de Medeiros, e publicada, tenha-se em conta, no órgão oficial do PRR, já deixava claro, por meio de um parágrafo lapidar, o que se entendia como regime penitenciário pelos castilhistas:

Em verdade, o estabelecimento do régimen presidenciario [sic], que aqui se está praticando, si por um lado amenisa a pena, por outro traz a salutar consequencia de evitar que o recluso se torne, na expressão do gasto chavão, um parasyta que ali vá sugar e nutrir-se da seiva do nosso organismo, em detrimento da sociedade (A Federação, 27 nov. 1900, p. 1).

Note-se, novamente, que não cabia no modelo penitenciário implementado pelos republicanos sul-rio-grandenses uma "forma econômica vazia", o trabalho só teria sentido, se para além de tirar os presos da ociosidade, gerasse dividendos. Apenas desse modo os encarcerados deixariam de ser parasitas que se nutriam do organismo, em detrimento da sociedade. Era somente com as rendas de seu trabalho, continuava o texto, que o "delinquente" atenderia à sua

subsistencia, às despezas do processo, à satisfação do danno, e ainda ao chegar o termo de sua segregação, encontra-se com um peculio formado, que servirá para inicio de nova vida em que, talvez, si a regeneração se operou e si foi extirpado de sua consciencia o germen funesto da delinquencia, possa ser útil a si e aos seus (A Federação, 27 nov. 1900, p. 1). 
Revelar-se-ia, todavia, o que se acostumou ocultar nas eufóricas e encomiásticas matérias publicadas ao longo do período em análise, mas bastante conhecido por qualquer preso que cumprisse pena nas oficinas da Casa de Correção: a fórmula do êxito. Pelo que se viu até agora, a matriz ideológica sempre foi muito clara, mas não os métodos e ingredientes de aplicação do sistema correcional, motivo pelo qual as seguintes palavras guardam sua devida importância:

[...] o regimen severo, sob a immediata fiscalização dos guardas, modera e refrêa os desregramentos e as exaltações de um temperamento não ordenado, como tambem o habito adquirido de trabalhar ha de forçosamente modificar as condições de existencia, despertando, salvo o caso do predominio de impulsos egoísticos indomaveis, o gosto pelas occupações honestas e lucrativas (A Federação, 27 nov. 1900, p. 1).

Como era de se esperar, o êxito econômico tinha seu próprio preço: a severidade do regime e o controle infligido pelos guardas. Em 1915, quando certamente questionada a excessiva carga horária de trabalho penitenciário, a resposta dada pelo então administrador foi a de que "não é tal modo de proceder uma originalidade do nosso Estado, pois o systema penitenciário moderno, recommenda a occupação diária do detento, o maior número de horas possível" (Frederico Ortiz apud Cesar, Szczepaniak, 2019, p. 303). Some-se a isso a tentativa por parte do mesmo funcionário em diminuir a fatia dos dividendos correspondente aos presos, ao sugerir

uma revisão sobre o referido rateio dos lucros, alegando que o aumento da produção também gerava a elevação das despesas. Ao contrário das duas partes destinadas aos presos que era depositada em seu nome na Caixa Econômica, Ortiz propunha que 4/5 do lucro dos produtos das oficinas passassem ao Estado e apenas se reservassem 1/5 aos encarcerados (Cesar, Szczepaniak, 2019, p. 305).

Controle, submissão e resignação foram, certamente, mais do que palavras de ordem, pois se faziam presentes dos regulamentos à prática cotidiana de encarceramento e trabalho.

Embora a ideia fosse inculcar o "gosto pelas occupações honestas e lucrativas", é difícil saber em que medida o regime realmente produzia indivíduos morigerados. Da mesma forma, se é verdade que muitas das oficinas iam de vento em popa, por outra parte não se atendia totalmente à determinação de privação de liberdade em regime celular. Parece, inclusive, que o êxito econômico fez sombra a esse descumprimento durante praticamente duas décadas, uma vez que só veio a ser denunciado publicamente na imprensa gaúcha, no final dos anos 1920.

Por certo, uma das primeiras reportagens em que se exigiu satisfações ao governo do estado durante a República Velha foi a que se publicou no Estado do Rio Grande, em 23 de novembro de 1929. Sob o título "O problêma penitenciario", acrescentaram-se outras duas 
chamadas: "Cumpre ao govêrno resolve-lo immediatamente" e "A segregação noturna dos presos é medida indispensavel e que exige um novo estabelecimento penitenciario". No meio da matéria se inseriu uma foto do estabelecimento, acompanhado da subsequente legenda: "A Casa de Correcção, edificio antigo e incapaz de cumprir a sua finalidade" (Estado do Rio Grande, 23 nov. 1929, p. 6).

A maldita prisão celular, considerada por Borges uma das "aberrações" do século passado (Medeiros, 1898, p. 22), voltava a assombrar. A denúncia não podia ser mais clara, o sistema penitenciário, baseado na segregação noturna e no trabalho obrigatório em comum, não era totalmente observado na Casa de Correção, já que dos dois preceitos, apenas o segundo "existe" e "muito bem organizado". Borges sabia disso perfeitamente, tanto que ainda no início do século afirmou que "o trabalho em commum dos condemnados substitue com vantagem a prisão simples ou o isolamento cellular". Concorde com sua opinião de anos antes, expressava então, novamente, contrariedade em relação ao sistema penal baseado na "reclusão cellular", alegando que "é por enquanto impraticavel, dada a falta de estabelecimentos especiaes vasados nos moldes que Bentham e outros idearam” (Medeiros, 1903, p. 6).

Voltando à reportagem, fazendo-se alusão a um relatório de 1926, apresentado ao governo do estado pelo desembargador Ribeiro Dantas, então presidente do Conselho Penitenciário, afirmava-se que de lá para cá nada se tinha feito, arriscando-se a perder o efeito moral da pena sobre os sentenciados (Estado do Rio Grande, 23 nov. 1929, p. 6). Podemos, portanto, fechar com a conclusão de Santos, de que as "autoridades brasileiras apostaram na recuperação dos indivíduos a partir do convívio e do trabalho coletivo, rejeitando o isolamento celular" (Santos, 2009, p. 310).

Assim entende-se também por que, apesar da legenda que apontava a antiguidade do prédio e sua incapacidade de cumprir com seu papel, não se tenha exigido um novo estabelecimento, mas tão somente uma verba para a "remodelação imprescindivel e immediata" da Casa de Correção. Mas os problemas não paravam por aí. Internamente, sabe-se que, desde a implementação do regime correcional, sob a égide do PRR, a disciplina e o controle, sempre exaltados em relatórios e mensagens, nunca deixaram de ser burlados.

Apesar das proibições e castigos estipulados nos regulamentos, as trocas, transações, linguagens e sociabilidades, por exemplo, entre guardas e presos, continuaram caracterizando o cotidiano penitenciário, tal como registrara o Dr. Sebastião Leão em seu relatório de 1896 (Moreira, 2009, p. 245-297) e que lembra bem outros estudos sobre a "subcultura carcerária” (O’Brien, 1998, p. 184-187). ${ }^{42}$ Dentre os vários tipos de resistência ativa, como as frustradas ou exitosas iniciativas de evasão, ou as pequenas transgressões às normativas do estabelecimento, devem ainda ser computadas as tentativas de suicídio e as simulações de loucura. Resumidamente, "o encarcerado, enquanto agente de sua realidade, soube se apro-

42 Ver também: (O’Brien, 1982), em particular o capítulo três “The new prison subcultures”, p. 75-108. 
priar do sistema, criando códigos e regras próprias, utilizando as normas já existentes a seu favor" (Szczepaniak, 2004, p. 92-94).

\section{Referências}

ALBUQUERQUE NETO, Flavio de Sá Cavalcanti de. Prisões e o trabalho forçado no Brasil na segunda metade do século XIX. Passagens: Revista Internacional de História Política C Cultura Jurídica (Niterói). v. 9, n. 1, p. 40-57, 2017.

BODEA, Miguel. A greve de 1917: as origens do trabalhismo gaúcho. Porto Alegre: L\&PM, s.d.

CESAR, Tiago da Silva. A ilusão panóptica: encarcerar e punir nas imperiais cadeias da província de São Pedro (18501888). São Leopoldo: Oikos/Editora Unisinos, 2015.

CESAR, Tiago da Silva; SZCZEPANIAK, Ivone. "E se fôr bem executado, não deixará de preencher as vistas, unicas, que o produzirão, de moralizar os condenados por meio do trabalho": as oficinas da Casa de Correção de Porto Alegre (1855-1921). In: CESAR, Tiago da Silva et al. (org.). História, cultura e patrimônio: experiências de pesquisa. $2^{\mathrm{a}}$ ed. Porto Alegre: Editora Fi, 2019, p. 283-313.

CHAZKEL, Amy. Uma perigosíssima lição: a Casa de Detenção do Rio de Janeiro na primeira República. In: MAIA, Clarisa Nunes; ALBUQUERQUE NETO, Flávio de Sá; COSTA, Marcos; BRETAS, Marcos Luiz (orgs.). História das prisões no Brasil. Rio de Janeiro: Rocco, 2009, v. II, p. 7-45.

CRUZ, Lisiane Ribas. "A infância abandonadaé a sementeira do crime": o julgamento de menores pela Comarca de Santa Maria (1910-1927). Dissertação (Mestrado em História), Universidade do Vale do Rio dos Sinos. São Leopoldo, 2017.

DONZELOT, Jacques. Espacio cerrado, trabajo y moralización: génesis y transformaciones paralelas de la prisión y del manicomio. In: CASTEL, Robert; DONZELOT, Jacques; FOUCAULT, Michel et al. Espacios de Poder. $2^{a}$ ed., Madrid: La Piqueta, 1991, p. 27-51.

DUPRAT, Catherine. Punir et guérir: en 1819, la prison des philanthropes. In: PERROT, Michelle. L'impossible prison: recherches sur le système pénitentiaire au XIXe siècle. Paris: Seuil, 1980, p. 64-122.
FOUCAULT, Michel. Vigiar e punir: nascimento da prisão. 40ª ed. Petrópolis: Vozes, 2012.

HOWARD, John. El estado de las prisiones en Inglaterra y Gales. México: Fondo de Cultura Económica, 2003.

ISAIA, Artur Cesar. Catolicismo e autoritarismo no Rio Grande do Sul. Porto Alegre: Edipucrs, 1998.

MAINWARING, Scott. Igreja católica e politica no Brasil (1916-1985). São Paulo: Brasiliense, 1989.

MELOSSI, Dario; PAVARINI, Massimo. Cárcere e fábrica: as origens do sistema penitenciário (séculos XVI-XIX). Rio de Janeiro: Revan/ICC, 2006.

MOREIRA, Paulo Roberto Staudt. Entre o deboche e a rapina: os cenários sociais da criminalidade popular em Porto Alegre na segunda metade do século XIX. Porto Alegre: Armazém Digital, 2009.

O'BRIEN, Patricia. The promise of punishment: prisons in nineteenth-century France. Princeton/New Jersey: Princeton University Press, 1982.

O'BRIEN, Patricia. The prison on the continent: Europe, 1865-1965. In: MORRIS, Norval; ROTHMAN, David J. (orgs.). The Oxford history of the prison: the practice of punishment in Western society. New York/Oxford: Oxford University Press, 1998, p. 178-201.

PEDROSO, Rita de Cássia Ribeiro. "Treze anos estou contando nas grades da Correção": um estudo em memória dos "infelizes sentenciados" da Casa de Correção de Porto Alegre, 1896-1913. Dissertação (Mestrado em História), Pontifícia Universidade Católica do Rio Grande do Sul. Porto Alegre, 2003.

PESAVENTO, Sandra Jatahy. Visões do cárcere. Porto Alegre: Zouk, 2009

REICHEL, Heloisa Jochims. A indústria têxtil do Rio Grande do Sul (1910-1930). Porto Alegre: Mercado Aberto, 1980.

RUSCHE; Georg; KIRCHHEIMER, Otto. Punição e estrutura social. $2^{2}$ ed. Rio de Janeiro: Revan, 2004. 
SALLA, Fernando. As prisões em São Paulo: 1822-1940. $2^{2}$ ed. São Paulo: Annablume/Fapesp, 2006.

SANT'ANNA, Marilene Antunes. A imaginação do castigo: discursos e práticas sobre a Casa de Correção do Rio de Janeiro. Tese (Doutorado em História), Universidade Federal do Rio de Janeiro. Rio de Janeiro, 2010.

SANTOS, Myrian Sepúlveda dos. Os porões da República: a barbárie nas prisões da Ilha Grande (1894-1945). Rio de Janeiro: Garamond, 2009.

SZCZEPANIAK, Ivone. A busca pelo cárcere perfeito: Casa de Correção de Porto Alegre (1835-1913). Dissertação (Mestrado em História), Universidade Federal de Santa Maria. Santa Maria, 2004.

TOCQEVILLE, Alexis de; BEAUMONT, Gustave de. Del sistema penitenciario en Estados Unidos y su aplicación en Francia. Madrid: Tecnos, 2005.

\section{Fontes Impressas}

BELLO, Luiz Alves Leite de Oliveira. Relatorio com que o vice-presidente Luiz Alves Leite de Oliveira Bello entregou a presidencia da Província de S. Pedro do Rio Grande do Sul ao Exm. Sr. Barão de Muritiba, no dia 26 de setembro de 1855. Porto Alegre: Typographia do Mercantil, 1855.

GONÇALVES, Carlos Barbosa. Mensagem enviada à Assembléa dos Representantes do Estado do Rio Grande do Sul pelo Dr. Carlos Barbosa Gonçalves na $1^{\underline{a}}$ sessão ordinaria da $6^{a}$ legislatura, em 20 de setembro de 1909. Porto Alegre: Officinas Graphicas da Livraria do Globo, 1909.

GONÇALVES, Carlos Barbosa. Mensagem enviada à Assembléa dos Representantes do Estado do Rio Grande do Sul pelo Dr. Carlos Barbosa Gonçalves na $3^{\underline{a}}$ sessão ordinaria da $6^{a}$ legislatura, em 20 de setembro de 1911. Porto Alegre: Officinas Graphicas da Livraria do Globo, 1911.

GONÇALVES, Carlos Barbosa. Mensagem enviada à Assembléa dos Representantes do Estado do Rio Grande do Sul pelo Dr. Carlos Barbosa Gonçalves na 4ª sessão ordinaria da 6 legislatura, em 20 de setembro de 1912. Porto Alegre: Officinas Graphicas da Livraria do Globo, 1912.

MACHADO, Salvador Ayres Pinheiro. Mensagem enviada à Assembléa dos Representantes do Estado do Rio Grande do Sul pelo Vice-Presidente em Exercicio General Salvador Ayres Pinheiro Machado na $1^{a}$ sessão ordinaria da 9a legislatura, em 20 de setembro de 1915. Porto Alegre: Officinas Graphicas d'A Federação, 1915.
MACHADO, Salvador Ayres Pinheiro. Mensagem en viada à Assembléa dos Representantes do Estado do Rio Grande do Sul pelo Vice-Presidente em Exercicio General

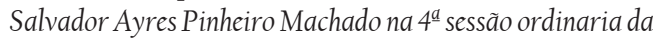
$7^{a}$ legislatura, em 20 de setembro de 1916. Porto Alegre: Officinas Graphicas d'A Federação, 1916.

MEDEIROS, Antonio Augusto Borges de. Mensagem enviada à Assembléa dos Representantes do Estado do Rio Grande do Sul pelo Presidente Antonio Augusto Borges de Medeiros na $2^{\underline{a}}$ sessão ordinaria da $3^{\underline{a}}$ legislatura, em 20 de setembro de 1898. Porto Alegre: Officinas Typographicas d'A Federação, 1898.

MEDEIROS, Antonio Augusto Borges de. Mensagem enviada à Assembléa dos Representantes do Estado do Rio Grande do Sul pelo Presidente Antonio Augusto Borges de Medeiros na $42^{\underline{a}}$ sessão ordinaria da $3^{\underline{a}}$ legislatura, em 20 de setembro de 1900. Porto Alegre: Officinas Typographicas d'A Federação, 1900.

MEDEIROS, Antonio Augusto Borges de. Mensagem enviada à Assembléa dos Representantes do Estado do Rio Grande do Sul pelo Presidente Antonio Augusto Borges de Medeiros, em 20 de setembro de 1903. Porto Alegre: Officinas Typographicas d'A Federação, 1903.

MEDEIROS, Antonio Augusto Borges de. Mensagem enviada à Assembléa dos Representantes do Estado do Rio Grande do Sul pelo Presidente Antonio Augusto Borges de Medeiros na 4a sessão ordinaria da 4ª legislatura, em 20 de setembro de 1904. Porto Alegre: Officinas Typographicas d'A Federação, 1904.

MEDEIROS, Antonio Augusto Borges de. Mensagem enviada à Assembléa dos Representantes do Estado do Rio Grande do Sul pelo Presidente Antonio Augusto Borges de Medeiros na $42^{\underline{a}}$ sessão ordinaria da $5^{\underline{a}}$ legislatura, em 20 de setembro de 1906. Porto Alegre: Officinas Typographicas d'A Federação, 1906.

MEDEIROS, Antonio Augusto Borges de. Mensagem enviada à Assembléa dos Representantes do Estado do Rio Grande do Sul pelo Presidente Antonio Augusto Borges de Medeiros na $3^{\underline{a}}$ sessão ordinaria da $5^{\underline{a}}$ legislatura, em 20 de setembro de 1907. Porto Alegre: Officinas Typographicas d'A Federação, 1907.

MEDEIROS, Antonio Augusto Borges de. Mensagem enviada à Assembléa dos Representantes do Estado do Rio Grande do Sul pelo Presidente Antonio Augusto Borges de Medeiros na $1^{\underline{a}}$ sessão ordinaria da $7^{\underline{a}}$ legislatura em, 20 de 
setembro de 1913. Porto Alegre: Officinas Typographicas d'A Federação, 1913.

MEDEIROS, Antonio Augusto Borges de. Mensagem enviada à Assembléa dos Representantes do Estado do Rio Grande do Sul pelo Presidente Antonio Augusto Borges de Medeiros na $1^{\underline{a}}$ sessão ordinaria da $3^{\underline{a}}$ legislatura, em 20 de setembro de 1914. Porto Alegre: Officinas Graphicas d'A Federação, 1914

MEDEIROS, Antonio Augusto Borges de. Mensagem enviada à Assembléa dos Representantes do Estado do Rio Grande do Sul pelo Presidente Antonio Augusto Borges de Medeiros na $1^{\underline{a}}$ sessão ordinaria da $8^{\underline{a}}$ legislatura, em 20 de setembro de 1917. Porto Alegre: Officinas Graphicas d'A Federação, 1917.

MEDEIROS, Antonio Augusto Borges de. Mensagem enviada à Assembléa dos Representantes do Estado do Rio Grande do Sul pelo Presidente Antonio Augusto Borges de Medeiros na $2^{\underline{a}}$ sessão ordinaria da $8^{\underline{a}}$ legislatura, em 20 de setembro de 1918. Porto Alegre: Officinas Graphicas d'A Federação, 1918.

MEDEIROS, Antonio Augusto Borges de. Mensagem e proposta de orçamento enviadas à Assembléa dos Representantes do Estado do Rio Grande do Sul pelo Presidente Antonio Augusto Borges de Medeiros na $3^{\underline{\underline{a}}}$ sessão ordinaria da $8^{\underline{a}}$ legislatura, em 20 de setembro de 1919. Porto Alegre: Officinas Graphicas d'A Federação, 1919.

MEDEIROS, Antonio Augusto Borges de. Mensagem e proposta de orçamento enviadas à Assembléa dos Representantes do Rio Grande do Sul pelo Presidente do Estado Antonio Augusto Borges de Medeiros na 4aㅡ sessão ordinaria da $8^{\underline{a}}$ legislatura, em 20 de setembro de 1920. Porto Alegre: Officinas Graphicas d'A Federação, 1920.

MEDEIROS, Antonio Augusto Borges de. Mensagem e proposta de orçamento enviadas à Assembléa dos Representantes do Rio Grande do Sul pelo Presidente do Estado Antonio Augusto Borges de Medeiros na $1^{\underline{a}}$ sessão ordinaria da $9^{\underline{a}}$ legislatura, em 20 de setembro de 1921. Porto Alegre: Officinas Graphicas d'A Federação, 1921.

MEDEIROS, Antonio Augusto Borges de. Mensagem enviada à Assembléa dos Representantes do Rio Grande do Sul pelo Presidente do Estado Antonio Augusto Borges de Medeiros na $2^{\underline{a}}$ sessão ordinaria da $9^{\underline{a}}$ legislatura, em 20 de setembro de 1922. Porto Alegre: Officinas graphicas d' A Federação, 1922.

MEDEIROS, Antonio Augusto Borges de. Mensagem enviada à Assembléa dos Representantes do Rio Grande do Sul pelo Presidente do Estado Antonio Augusto Borges de Medeiros na $3^{\underline{a}}$ sessão ordinaria da 9aㅡ legislatura, em 29 de novembro de 1923. Porto Alegre: Officinas Graphicas d'A Federação, 1923.

MEDEIROS, Antonio Augusto Borges de. Mensagem enviada à Assembléa dos Representantes do Rio Grande do Sul pelo Presidente do Estado Antonio Augusto Borges de

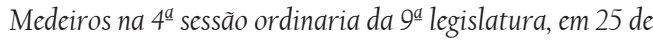
outubro de 1924. Porto Alegre: Officinas Graphicas d'A Federação, 1924.

MEDEIROS, Antonio Augusto Borges de. Mensagem enviada à Assembléa dos Representantes do Rio Grande do Sul pelo Presidente do Estado Antonio Augusto Borges de Medeiros na $2^{\underline{a}}$ sessão ordinaria da 10 $10^{\underline{a}}$ legislatura, em 23 de setembro de 1926. Porto Alegre: Officinas Graphicas d' A Federação, 1926.

MEDEIROS, Antonio Augusto Borges de. Mensagem enviada à Assembléa dos Representantes do Rio Grande do Sul pelo Presidente do Estado Antonio Augusto Borges de Medeiros na $3^{\underline{a}}$ sessão ordinaria da $10^{\underline{a}}$ legislatura, em 20 de setembro de 1927. Porto Alegre: Officinas Graphicas d'A Federação, 1927.

VARGAS, Getulio. Mensagem enviada à Assembléa dos Representantes do Rio Grande do Sul pelo Presidente do Estado Getulio Vargas, na $4^{a}$ sessão ordinaria da $10^{\underline{a}}$ legislatura, em 20 de setembro de 1928. Porto Alegre: Officinas Graphicas d'A Federação, 1928.

VARGAS, Getulio. Mensagem enviada à Assembléa dos Representantes do Rio Grande do Sul pelo Presidente do Estado Getulio Vargas, na $1^{\underline{a}}$ sessão ordinaria da $11^{\underline{a}}$ legislatura, em 20 de setembro de 1929. Porto Alegre: Officinas Graphicas d'A Federação, 1929.

VARGAS, Getulio. Mensagem enviada à Assembléa dos Representantes do Rio Grande do Sul pelo Presidente do Estado Getulio Vargas, na $2^{\underline{a}}$ sessão ordinaria da $11^{a}$ legislatura, em 20 de setembro de 1930. Porto Alegre: Officinas Graphicas d'A Federação, 1930. 